\title{
Health Risk Assessment of Heavy Metals in Manila Catfish (Arius dispar) from Laguna Lake
}

\author{
Victorio B. Molina
}

Department of Environmental and Occupational Health, College of Public Health, University of the Philippines Manila

\begin{abstract}
Objective. The main objective of this study is to provide an assessment of the risks to human health associated with the exposure to heavy metal bioaccumulation in Manila Catfish (Arius dispar) from Laguna Lake.

Methods. Manila Catfish (common name Kanduli) samples were collected in eight sampling stations in three major areas of the lake during the dry and wet seasons. Dry season samples were collected from May to June 2010 and wet season samples from September to November 2010. Coordinates of sampling locations were recorded using Global Positioning System to facilitate re-sampling activities and ensured that subsequent samples for the wet season were collected in the area as that of the wet season samples. Heavy metals analyses for cadmium, lead, arsenic, and chromium were conducted using Atomic Absorption Spectrophotometer and Mercury Analyzer for mercury. Estimates of health risks associated with Kanduli consumption were estimated based on non-carcinogenic health effects of heavy metals.
\end{abstract}

Results. Non-carcinogenic Health Quotient (NHQ) values of the five heavy metals showed that lead is the most significant pollutant of concern in terms of adverse health effects from risks associated with Kanduli consumption from the lake.

Conclusion. From the point of view of disease prevention and control, long term consumption of Kanduli from Laguna Lake is expected to increase health risk due to lead contamination.

Key Words: bioaccumulation, Manila Catfish, lead, arsenic, cadmium, chromium, mercury, heavy metals, health risk assessment, Laguna Lake

\section{Introduction}

Heavy metals, nutrients, and other chemical contaminants are transported in water bodies, dissolved or associated to sediment particles. It is known that the

\footnotetext{
Corresponding author: Victorio B. Molina, MPH, PhD

Department of Environmental and Occupational Health

College of Public Health

University of the Philippines Manila

625 Pedro Gil Street, Ermita, Manila, 1000 Philippines

Telephone: +632 5247102

Fax No.: +6325237745

Email: vbmolina@post.upm.edu.ph
}

dissolved divalent ionic form of trace metals is toxic to the biota, while the adsorbed or particulate fraction is considered biologically unavailable. ${ }^{1}$ Heavy metals are among the more serious pollutants in our natural environment due to their toxicity, persistence and bioaccumulation problems. ${ }^{2}$ Pollution of heavy metals in aquatic ecosystem is growing at an alarming rate and has become an important global problem. ${ }^{3}$ With increased urbanization and industrialization, there has been a rapid increase in domestic and industrial wastewater which has intensified the environmental pollution in different environmental compartments. The major sources of contamination in surface waters can be traced to industrial discharges, domestic waste disposal and application of agrochemicals on farmlands. The pollutants like heavy metals after entering into aquatic environments accumulate in tissues and organs of aquatic organisms. ${ }^{4}$ These contaminants may not directly damage the organisms but they can be deposited through the effects of bioaccumulation and food chain process that eventually threaten the health of humans through fish consumption. ${ }^{5}$

Biomagnifications of trace elements in living organisms describes the processes and pathways of these potential pollutants from one trophic level to another, exhibiting the higher bioaccumulation ability in the organisms concerned. Increasing concentration through the food chain caused higher retention time of toxic substances than that of the other normal food components. ${ }^{6}$ Fish is considered as one of the most important indicators in freshwater ecosystems for the estimation of trace metals pollution. They are positioned at high trophic level of the food web and may accumulate large amounts of heavy metals from the water and often in concentrations several times higher than in the ambient water. ${ }^{7}$ On the other hand, fish has been known for its reputation as the established health food for most of the world's population particularly developing countries in contrast to meat, poultry and eggs. The protein content in fish averages from 15 to 20 percent; hence fish provides comparatively cheap and readily available protein sources in complement with long chains of n-3 fatty acids, amino acids, vitamins and minerals that further contributes to healthy nutritional options for a balance dietary intake. ${ }^{8}$ Health risk of heavy metals bioaccumulation in fish therefore is 
important to establish scientific basis for understanding risks versus benefits of fish consumption.

The Philippine Millennium Ecosystem Assessment Subglobal Assessment for Laguna Lake emphasized that the Laguna Lake Basin is a classic model of a multiple resource with multiple users. Its capacity to provide various ecosystem services to various users is continuously being challenged mainly by anthropogenic factors. Lake water quality has deteriorated through the years due to various point sources of pollution from industry, agriculture, and domestic sources. Detection of traces of heavy metals like copper, cadmium, chromium, and lead in the water and sediment is a major concern for human health. ${ }^{9}$ The main objective of the study is to assess the risks to human health associated with the exposure to heavy metals bioaccumulation of Manila Catfish (Kanduli) from Laguna Lake. Kanduli is the species of choice in this study mainly because of its characteristics as a bottom dweller and as one of the most common edible fish harvested from the lake throughout the year.

\section{Method}

\section{Sampling Zones and Sites}

Laguna Lake, the largest inland body of water in the Philippines, was arbitrarily divided into five sampling zones: namely, Northern West Bay, Central West Bay, Central Bay, South Bay, and East Bay. These zones were selected to represent different areas of the lake with fishing operations. Kanduli samples were collected from each of the five designated sampling zones in the lake. There were two sampling sites each for Northern West Bay, Central West Bay, and Central Bay; and one sampling site each for South Bay, and East Bay; for a total of eight sampling sites. Allocation of number of sampling sites in the five sampling zones was based on the degree of fishing operations in the zone. Summary of sampling zones and sites is shown in Table 1. Fishing operations in the sampling sites are basically aquaculture and open water fisheries. Samples were collected in the open water because Kanduli is not normally propagated in fish pens or cages. About three to five fish samples of marketable size were collected per sampling station. Sizes of fish samples were comparable for both the wet and dry seasons.

Table 1. Sampling zones and sites

\begin{tabular}{ccc}
\hline $\begin{array}{c}\text { SAMPLING } \\
\text { ZONES }\end{array}$ & NAME & $\begin{array}{c}\text { NUMBER OF } \\
\text { SAMPLING SITE/S }\end{array}$ \\
\hline 1 & Northern West Bay & 2 \\
2 & Central West Bay & 2 \\
3 & Central Bay & 2 \\
4 & South Bay & 1 \\
5 & East Bay & 1 \\
& TOTAL & 8 \\
\hline
\end{tabular}

The coordinates of the sampling locations (latitude and longitude) of the eight stations in the different zones were recorded using a Global Positioning System (GPS) instrument and plotted in Geographic Information System (GIS) digital maps. The locations and coordinates of the sampling sites are shown in Table 2. This facilitated resampling activities and ensured that subsequent samples for the wet season were collected in the area as that of the wet season samples. A GIS map of Laguna de Bay showing the sampling zones is shown in Figure 1.

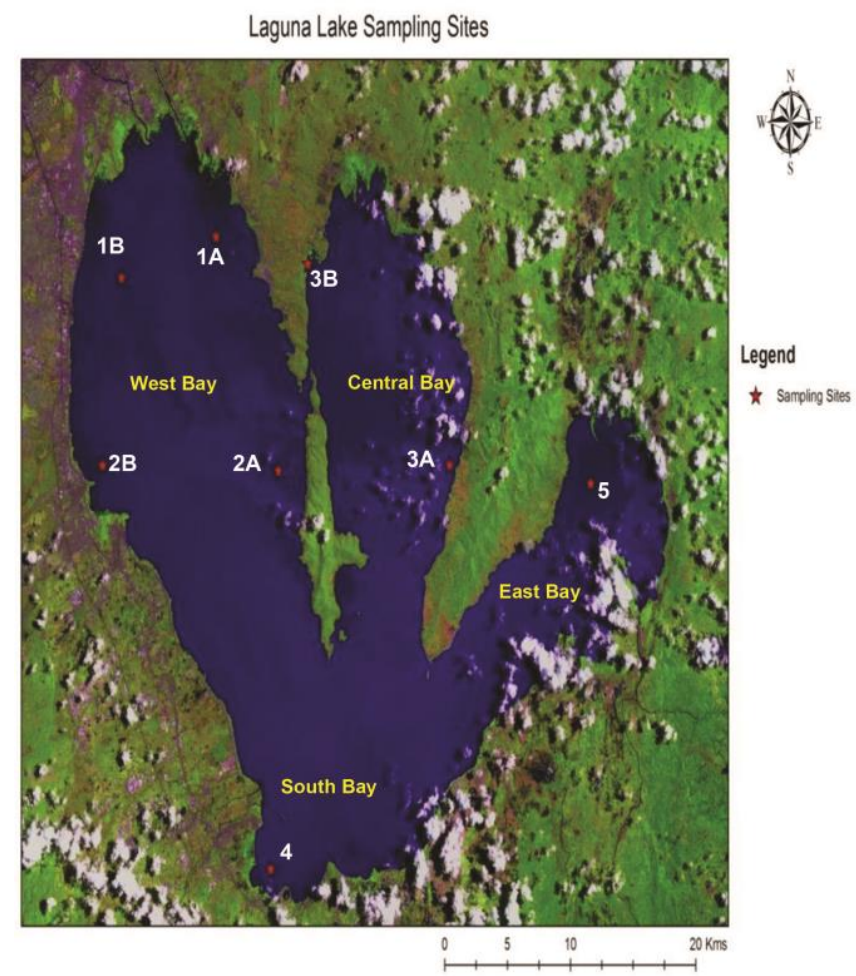

Figure 1. Location of sampling sites (GIS map).

Table 2. Sampling site locations and coordinates.

\begin{tabular}{|c|c|c|}
\hline FISH SAMPLING SITE & LOCATION & COORDINATES \\
\hline $1 \mathrm{~A}$ & Northern West Bay & $\mathrm{N} 14^{\circ} 28^{\prime} 57.8^{\prime \prime}$ \\
\hline (Binangonan) & & E $121^{\circ} 09^{\prime} 22.6^{\prime \prime}$ \\
\hline $1 \mathrm{~B}$ & Northern West Bay & $\mathrm{N} 14^{\circ} 27^{\prime} 50.6^{\prime \prime}$ \\
\hline (Taguig) & & E $121^{\circ} 05^{\prime} 19.3^{\prime \prime}$ \\
\hline $2 \mathrm{~A}$ & Central West Bay & $\mathrm{N} 14^{\circ} 22^{\prime} 34.1^{\prime \prime}$ \\
\hline (Talim Island) & & E $121^{\circ} 12^{\prime} 03.6^{\prime \prime}$ \\
\hline $2 \mathrm{~B}$ & Central West Bay & $\mathrm{N} 14^{\circ} 22^{\prime} 43.4^{\prime \prime}$ \\
\hline (Sta Rosa) & & E $121^{\circ} 04^{\prime} 30.1^{\prime \prime}$ \\
\hline $3 \mathrm{~A}$ & Central Bay & $\mathrm{N} 14^{\circ} 22^{\prime} 43.9^{\prime \prime}$ \\
\hline (Jala-Jala) & & E $121^{\circ} 19^{\prime} 25.5^{\prime \prime}$ \\
\hline 3B & Central Bay & $\mathrm{N} 14^{\circ} 28^{\prime} 13.5^{\prime \prime}$ \\
\hline (Cardona) & & E $121^{\circ} 13^{\prime} 19.4^{\prime \prime}$ \\
\hline 4 & South Bay & $\mathrm{N} 14^{\circ} 11^{\prime} 41.4^{\prime \prime}$ \\
\hline (Calamba) & & E $121^{\circ} 11^{\prime} 43.5^{\prime \prime}$ \\
\hline 5 & East Bay & $\mathrm{N} 14^{\circ} 22^{\prime} 12.9^{\prime \prime}$ \\
\hline (Pakil) & & E $121^{\circ} 25^{\prime} 28.8^{\prime \prime}$ \\
\hline
\end{tabular}




\section{Sampling Frequency}

There were two batches of fish samples collected from open water fishery. The first batch of fish samples was collected in May to June 2010 to represent the dry season conditions in the study area. The second batch of fish samples was collected during the months of September to November 2010 to represent wet season conditions.

\section{Heavy Metals Included in the Study}

The heavy metals included in the study were cadmium $(\mathrm{Cd})$, lead $(\mathrm{Pb})$, mercury $(\mathrm{Hg})$, arsenic (As), and chromium $(\mathrm{Cr})$. These non-essential metals from the point of view of human health are also known to have the ability to bioaccumulate and biomagnify through the food chain.

\section{Sample Packaging and Preservation}

Fish samples were individually wrapped in a waterproof plastic sampling bag. The edible portions of fish samples were processed on-site to avoid puncturing of the packaging material by the fish spines. Individual fish samples were sealed in the plastic bags and packed in a large plastic bag. Each sample was provided with an identification tag and sample code. After packaging, the samples were kept in an ice chest with ice and brought to the laboratory on the day of sampling.

\section{Laboratory Procedures and Analysis}

Samples submitted to the laboratory were stored in the freezer until all the samples had been collected to ensure uniform sample preparation. Prior to analyses, samples were thawed then osterized for homogeneity. Replicates were prepared and all quality control parameters were conducted to ensure integrity of the analyses. Cadmium, chromium and lead were analyzed using the AAS (Atomic Absorption Spectrometer). The sample solutions were aspirated into a flame and atomized.

Arsenic analysis involves the generation of arsine gas by reacting the arsenic in the sample with sodium borohydride. Reaction takes place in a hydride generation assembly that is attached to an AAS system.

Mercury in the fish samples was analyzed using the Mercur-Duo Mercury Analyzer, a single-beam instrument with a mercury low-pressure lamp as a light source for the excitation of mercury atoms and a photomultiplier to record the fluorescent or absorption radiation.

\section{Estimate of Potential Human Exposure to Heavy Metal}

The basic equation for calculating systemic toxicity (non-carcinogenic hazard) is:

$$
\mathrm{NHQ}=\frac{\mathrm{CDI}}{\mathrm{RfD}}
$$

where:

NHQ = Non-carcinogenic Hazard Quotient

CDI = chronic daily intake for the toxicant expressed in $\mathrm{mg} / \mathrm{kg}$-day

$\mathrm{RfD}=$ chronic (oral) reference dose for the toxicant expressed in $\mathrm{mg} / \mathrm{kg}$-day.

Chronic oral reference dose (RfD) is defined as an estimate (with uncertainty spanning perhaps an order of magnitude or greater) of a daily oral exposure level for the human population, including sensitive subpopulations, that is likely to be without an appreciable risk of deleterious effects during a lifetime. Chronic oral RfDs are specifically developed to be protective for long-term exposure to a compound. As a guideline, chronic oral RfDs generally should be used to evaluate the potential non-carcinogenic effects associated with exposure periods greater than 7 years (approximately 10 percent of a human lifetime). Chronic oral reference doses are expressed in units of $\mathrm{mg} / \mathrm{kg}$-day. The RfD values of heavy metal in this study were adopted from USEPA. For Arsenic, RfD=0.0003 mg/kg-day, Chromium, $\mathrm{RfD}=0.003 \mathrm{mg} / \mathrm{kg}$-day, Mercury, $\quad 0.0001 \mathrm{mg} / \mathrm{kg}$-day, Cadmium, RfD=0.001 mg/kg-day, and Lead, Rfd=0.0000001 $\mathrm{mg} / \mathrm{kg}$-day. ${ }^{10}$

Non-Carcinogenic Fish Ingestion Equation: CDI(nc)

$$
\begin{aligned}
& \mathrm{CDI}(\mathrm{nc})=\underline{\mathrm{C} \times \mathrm{EF} \times \mathrm{ED} \times \operatorname{IRF} \times(\mathrm{kg} / 1000 \mathrm{~g})} \\
& \text { (365 days/year) } \times \text { LT } \times \text { BW }
\end{aligned}
$$

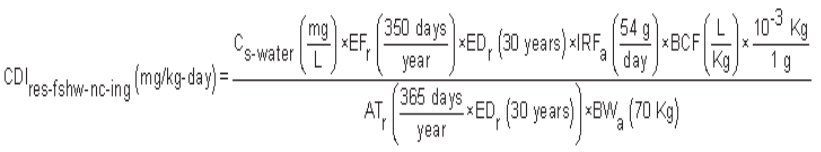

Where:

CDI = chronic daily intake for the toxicant expressed in $\mathrm{mg} / \mathrm{kg}$-day

C = Concentration of heavy metal in fish $(\mathrm{mg} / \mathrm{kg})$

BW = Body Weight (Average value for Filipino adult $\sim 65$ kgs.)

$\mathrm{ED} \quad=$ Exposure Duration (30 years)

$\mathrm{EF} \quad=$ Exposure frequency (350 days/year)

IRF =Ingestion Rate Fish (fish consumption) $=102.74$ $\mathrm{g} /$ day (FAO). This is the estimated average daily per capita consumption of fish in the Philippines from the FAO Fisheries and Aquatic Department.

LT = Lifetime (average), 30 years for non-carcinogenic health effects 
The Non-carcinogenic Hazard Quotient (NHQ) is one of the measures of non-carcinogenic health effects of exposure to chemical contaminants. It is the ratio of an exposure level by a contaminant to a reference dose or value selected for the health risk assessment of a particular substance or chemical. If the exposure level is higher than the toxicity value, then there is the potential for risk to the receptor. Computed NHQ value of greater than 1.0 indicates that the exposure to a single chemical or substance will likely result to adverse health effects. The potential health effects are dependent on the type of chemical or substance of concern. NHQ values of 1.0 or below indicates that daily oral exposure level for the human population, including sensitive subpopulations, is likely to be without an appreciable risk of deleterious effects during a lifetime. ${ }^{10-12}$

\section{Results}

Results on the heavy metal concentrations in the edible portions of collected Kanduli samples are divided into two categories: (1) Heavy metal levels in Kanduli for dry season, and (2) Heavy metal levels in Kanduli for wet season.

\section{(1) Heavy metal levels in Kanduli for dry season}

Table 3 shows the concentrations of heavy metal $(\mathrm{Cd}$, $\mathrm{Cr}, \mathrm{Pb}, \mathrm{Hg}$ and $\mathrm{As}$ ) in Kanduli from eight sampling stations during the dry season. Cadmium (Cd) concentration ranged from $0.00731 \mathrm{mg} / \mathrm{kg}$ in sampling station $1 \mathrm{~A}$ to $0.0809 \mathrm{mg} / \mathrm{kg}$ in station 3B. Chromium $(\mathrm{Cr})$ ranged from $0.03304 \mathrm{mg} / \mathrm{kg}$ in station $1 \mathrm{~A}$ to $0.12631 \mathrm{mg} / \mathrm{kg}$ in station $2 \mathrm{~B}$. Lead $(\mathrm{Pb})$ ranged from $0.283114 \mathrm{mg} / \mathrm{kg}$ in station $2 \mathrm{~A}$ to $6.8581 \mathrm{mg} / \mathrm{kg}$ in station 4. Mercury $(\mathrm{Hg})$ ranged from $0.00347 \mathrm{mg} / \mathrm{kg}$ in station 4 to $0.15807 \mathrm{mg} / \mathrm{kg}$ in station 3B. Arsenic (As) ranged from $0.00003 \mathrm{mg} / \mathrm{kg}$ in station $3 \mathrm{~B}$ to $0.73765 \mathrm{mg} / \mathrm{kg}$ in station 3A.

Table 3. Heavy metal concentration $(\mathrm{mg} / \mathrm{kg})$, dry season

\begin{tabular}{cccccc}
\hline Sampling Site & $\mathbf{C d}$ & $\mathbf{C r}$ & $\mathbf{P b}$ & $\mathbf{H g}$ & As \\
\hline 1A & 0.00731 & 0.03304 & 1.31713 & 0.02733 & 0.36821 \\
1B & 0.03995 & 0.06510 & 0.58447 & 0.06064 & 0.01670 \\
2A & 0.03794 & 0.05595 & 0.28314 & 0.05797 & 0.14091 \\
2B & 0.05579 & 0.12631 & 1.57937 & 0.01078 & 0.20388 \\
3A & 0.07389 & 0.08206 & 0.77247 & 0.03893 & 0.73765 \\
3B & 0.08090 & 0.05461 & 0.97520 & 0.15807 & 0.00003 \\
4 & 0.07570 & 0.06487 & 6.85810 & 0.00347 & 0.06151 \\
5 & 0.04298 & 0.04018 & 0.38553 & 0.07166 & 0.20645 \\
\hline
\end{tabular}

(2) Heavy metal levels in Kanduli for wet season

Table 4 shows the concentrations of heavy metal $(\mathrm{Cd}$, $\mathrm{Cr}, \mathrm{Pb}, \mathrm{Hg}$ and $\mathrm{As}$ ) in Kanduli from eight sampling stations during the wet season. Cadmium $(\mathrm{Cd})$ concentration ranged from $0.0026 \mathrm{mg} / \mathrm{kg}$ in sampling station $2 \mathrm{~B}$ to $0.31835 \mathrm{mg} / \mathrm{kg}$ in station 1A. Chromium (Cr) ranged from $0.00134 \mathrm{mg} / \mathrm{kg}$ in station $3 \mathrm{~B}$ to $0.17079 \mathrm{mg} / \mathrm{kg}$ in station $1 \mathrm{~B}$. Lead $(\mathrm{Pb})$ ranged from $0.00973 \mathrm{mg} / \mathrm{kg}$ in station 2B to $6.49705 \mathrm{mg} / \mathrm{kg}$ in station 1A. Mercury $(\mathrm{Hg})$ ranged from $0.0127 \mathrm{mg} / \mathrm{kg}$ in station $2 \mathrm{~B}$ to
$0.03569 \mathrm{mg} / \mathrm{kg}$ in station 3B. Arsenic (As) ranged from 0.001 $\mathrm{mg} / \mathrm{kg}$ in stations $2 \mathrm{~A}, 2 \mathrm{~B}, 3 \mathrm{~A}, 3 \mathrm{~B}$ and 5 to $0.09517 \mathrm{mg} / \mathrm{kg}$ in station 4 .

Table 4. Heavy metal concentration $(\mathrm{mg} / \mathrm{kg})$, wet season.

\begin{tabular}{cccccc}
\hline Sampling Site & $\mathbf{C d}$ & $\mathbf{C r}$ & $\mathbf{P b}$ & $\mathbf{H g}$ & $\mathbf{A s}$ \\
\hline 1A & 0.31835 & 0.07272 & 6.49705 & 0.02167 & 0.08022 \\
1B & 0.27480 & 0.17079 & 1.93583 & 0.02402 & 0.09035 \\
2A & 0.00655 & 0.00275 & 1.85737 & 0.02338 & 0.00100 \\
2B & 0.00260 & 0.00696 & 0.00973 & 0.01270 & 0.00100 \\
3A & 0.00309 & 0.00168 & 0.01054 & 0.01332 & 0.00100 \\
3B & 0.01054 & 0.00134 & 0.11703 & 0.03569 & 0.00100 \\
4 & 0.00273 & 0.00237 & 0.04439 & 0.01853 & 0.09517 \\
5 & 0.00560 & 0.04147 & 0.01787 & 0.02560 & 0.00100 \\
\hline
\end{tabular}

\section{Discussion}

During the dry season, lead appeared to have the highest concentration in Kanduli particularly in sampling station 4 . The data showed that other heavy metals were fairly distributed in the different areas of the lake. In the wet season, concentrations of heavy metals in Kanduli were mostly detected in sampling stations 1A, 1B and 2A. Stations $1 \mathrm{~A}$ and $1 \mathrm{~B}$ are located in the Northern West Bay while 2A is located in the Central West Bay. Lead $(\mathrm{Pb})$ concentrations were highest in sampling stations $1 \mathrm{~A}, 1 \mathrm{~B}$ and $2 \mathrm{~A}$. It is also apparent that lead $(\mathrm{Pb})$ values were higher in the wet season than in the dry season in these three stations.

The results of laboratory analyses showed that the onset of the rainy season had both negative and positive effects on the heavy metal concentrations in Kanduli depending on its location in the lake. The positive outcome of rain could be due to the dilution effect of rainwater run-off which was apparent in the South bay, Central bay and East bay. On the other hand, the negative consequence of rain could be due to the "flushing-effect" from tributaries and run-off from adjoining areas with significant sources of heavy metals in the environmental compartments. This was observed in the West Bay where lead was highest during the wet season. In addition, during the dry season, decreasing level or depth of lake water allows the inflow of potentially contaminated water from the Pasig River.

Computed values of Non-carcinogenic Hazard Quotient (NHQ) of cadmium, chromium, lead, mercury and arsenic (in Kanduli) for all sampling stations during the dry season are summarized in Table 5. Results of the computations showed that NHQ values for cadmium, chromium, and arsenic are less than 1.0 (unit less value) in all sampling stations which indicate that the daily oral exposure level for the human population, including sensitive subpopulations, is likely to be without an appreciable risk of deleterious effects during a lifetime. However, NHQ value for mercury in sampling station $3 \mathrm{~B}$ during the dry season was greater than 1.0 (NHQ=2.16) which shows potential deleterious effects due to long term fish consumption. NHQ values for lead in all sampling stations are way above 1.0, indicating 
high risk for adverse human health effects associated with long-term Kanduli consumption.

Table 5. Summary of NHQ values for dry season.

\begin{tabular}{crrrrc}
\hline & \multicolumn{5}{c}{ NHQ Values (DS) } \\
\cline { 2 - 6 } Sampling Site & Cd & Cr & Pb & Hg & As \\
\hline 1A & 0.0111 & 0.0100 & 19963 & 0.3724 & 0.1860 \\
1B & 0.0606 & 0.0197 & 8859 & 0.8272 & 0.0084 \\
2A & 0.0575 & 0.0170 & 4291 & 0.7908 & 0.0712 \\
2B & 0.0846 & 0.0383 & 23938 & 0.1470 & 0.1030 \\
3A & 0.1120 & 0.0249 & 11708 & 0.5310 & 0.3727 \\
3B & 0.1226 & 0.0166 & 14781 & 2.1562 & 0.0000 \\
4 & 0.1147 & 0.0197 & 103945 & 0.0473 & 0.0311 \\
5 & 0.0651 & 0.0122 & 5843 & 0.9775 & 0.1043 \\
\hline
\end{tabular}

For the wet season, computed values of Noncarcinogenic Hazard Quotient (NHQ) of cadmium, chromium, lead, mercury and arsenic in Kanduli for all sampling stations are summarized in Table 6. The NHQ values for cadmium, chromium, mercury and arsenic were less than 1.0 in all sampling stations. However, NHQ values for lead in all sampling stations were way above 1.0, indicating high risk for adverse human health effects associated with long-term Kanduli consumption.

Table 6. Summary of NHQ values for wet season.

\begin{tabular}{crrrrc}
\hline & \multicolumn{5}{c}{ NHQ Values (WS) } \\
\cline { 2 - 6 } Sampling Site & Cd & Cr & Pb & Hg & As \\
\hline 1A & 0.4825 & 0.0220 & 98473 & 0.2956 & 0.0405 \\
1B & 0.4165 & 0.0518 & 29341 & 0.3277 & 0.0456 \\
2A & 0.0099 & 0.0008 & 28151 & 0.3189 & 0.0005 \\
2B & 0.0039 & 0.0021 & 147 & 0.1732 & 0.0005 \\
3A & 0.0047 & 0.0005 & 160 & 0.1817 & 0.0005 \\
3B & 0.0160 & 0.0004 & 1774 & 0.4868 & 0.0005 \\
4 & 0.0041 & 0.0007 & 673 & 0.2528 & 0.0481 \\
5 & 0.0085 & 0.0126 & 271 & 0.3492 & 0.0005 \\
\hline
\end{tabular}

\section{Conclusion}

Results of the study showed that arsenic, cadmium, and chromium do not pose significant non-carcinogenic health effects $(\mathrm{NHQ}<1.0)$ associated with long term consumption of Kanduli from Laguna Lake. However, NHQ value for mercury in sampling station $3 \mathrm{~B}$ during the dry season was greater than $1.0 \quad(\mathrm{NHQ}=2.16)$ which shows potential deleterious effects due to chronic fish consumption. Computed NHQ values for lead $(\mathrm{Pb})$ in Kanduli showed highly elevated levels that are likely to cause adverse health effects on fish consumers overtime. This study therefore concludes that from the point of view of human health protection and disease prevention, long-term consumption of Kanduli from Laguna lake is not safe mainly because of the levels of lead that were found to be extremely above the acceptable NHQ values.

\section{Recommendations}

In the light of the above findings, the following recommendations for policy makers and other concerned stakeholders:

- Urgent mitigating measures should be done by concerned authorities to protect health of communities consuming Kanduli from the lake especially the children.

- Regular monitoring of heavy metals in fishes should be done at least twice a year.

- Issuance of regular health advisories regarding quantitative health risks associated with Kanduli consumption from the Laguna Lake Development Authority or the Regional Office of the Department of Health.

- Involvement of the Local Government Units in the lakeshore communities in terms of heavy metals monitoring in fish and in developing and disseminating advisories and other health-related information to the communities.

- Develop and implement an appropriate risk communication program for all stakeholders including but not limited to fishermen, fish pen owners, farmers, industries and the general public.

- Inventory and assessment of potential sources of heavy metals in the lake and more stringent regulation of effluents from industries around the lake.

- Regular monitoring of heavy metals in major rivers and tributaries draining into the lake.

\section{Acknowledgments}

I wish to extend my gratitude and appreciation to the following persons for their support and guidance: Dr. Maria Victoria O. Espaldon, Dr. Enrique P. Pacardo, Dr. Maxima E. Flavier, Dr. Carmelita M. Rebancos and Dr. Lynn Panganiban, Ms. Jacqueline Davo, Ms. Lennie Borja, Mr. Dong Estoy, Mr. Jess Futalan, Mr. Noely Sumadia, Mr. Val Ablaza and Mr. Melvin Martinez. To the Industrial Technology Development Institute, Department of Science and Technology laboratory for analyzing voluminous fish samples. My heartfelt gratitude to the Department of Environmental and Occupational Health, College of Public Health UP Manila, the Philippine Council for Health Research and Development - DOST, and the Research Institute for Humanity and Nature, Kyoto, Japan, for the financial assistance to this research work. Above all, highest honor and gratitude to our God Almighty, for His unconditional love and guidance, for giving me strength, perseverance, wisdom and discernment, to God be the glory! 


\section{References}

1. Laar C, Fianko JR, Akiti TT, Osae S, Brimah AK. Determination of heavy metals in the Black-Chin Tilapia from the Sakumo Lagoon, Ghana. Res J Environ Earth Sci. 2011; 3(1):8-13.

2. Odu NN, Igwiloh NJPN, Okonko IO, Njoku HO. Heavy metal levels of some edible shellfish from Kalarugbani Creek in River State, Nigeria. J Am Sci. 2011; 7(9):802-9.

3. Abdel-Baki AS, Dkhil MA, Al-Quraishy S. Bioaccumulation of some heavy metals in Tilapia fish relevant to their concentration in water and sediment of Wadi Hanifah, Saudi Arabia. Afr J Biotechnol. 2011; 10(13):2541-7.

4. Akan JC, Abdulrahman FI, Sodipo OA, Akandu PI. Bioaccumulation of some heavy metals of six fresh water fishes caught from Lake Chad in Doron Buhari, Maiduguri, Borno State, Nigeria. J Appl Sci Environ Sanit. 2009; 4(2):103-14.

5. Lakshmanan R, Kesavan K, Vijayanand P, Rajaram V, Rajagopal S. Heavy metals accumulation in five commercially important fishes of Parangipettai, Southeast Coast of India. Advance Journal of Food Science and Technology. 2009; 1(1):63-5.

6. Sreedhara Nayaka BM, Ramakrishna S, Jayaprakash, Delvi MR. Impact of heavy metals on water, fish (Cyprinus carpio) and sediments from a water tank at Tumkur, India. International Journal of Oceanography and Hydrobiology. 2009; 38(2):17-38.

7. Yousafzai AM, Chivers DP, Khan AR, Ahmad I, Siraj M. Comparison of heavy metals burden in two freshwater fishes Wallago attu and Labeo dyocheilus with regard to their feeding habits in natural ecosystem. Pakistan J Zool. 2010; 42(5):537-44.
8. Nor Hasyimah AK, James Noik V, Teh YY, Lee CY, Pearline Ng HC. Assessment of Cadmium $(\mathrm{Cd})$ and Lead $(\mathrm{Pb})$ levels in commercial marine fish organs between wet markets and supermarkets in Klang Valley, Malaysia. Int Food Res J. 2011; 18:795-802.

9. Lasco RD, Espaldon MVO, Tapia, MA. Ecosystems and People: The Philippine Millennium Ecosystem Assessment (MA) Sub-global Assessment. Environmental Forestry Program College of Forestry and Natural Resources University of the Philippines Los Baños, Department of Environment and Natural Resources (DENR), and Laguna Lake Development Authority (LLDA). 2005.

10. Integrated Risk Information System. US Environmental Protection Agency [online]. 2011 [cited 2011 June]. Available from http://www.epa.gov/iris/help_gloss.htm.

11. Extension Toxicology Network. Pesticide Information Project of Cooperative Extension Offices of Cornell University, Oregon State University, the University of Idaho, and the University of California at Davis and the Institute for Environmental Toxicology, Michigan State University [online]. 2011 [cited 2011 June]. Available from http://www.pmep.cce.cornell.edu/profiles/extoxnet/index.html.

12. A Guide to Health Risk Assessment, California Environmental Protection Agency. Office of Environmental Health Hazard Assessment [online]. 2011 [cited 2011 March]. Available from http://www.oehha.ca.gov/.

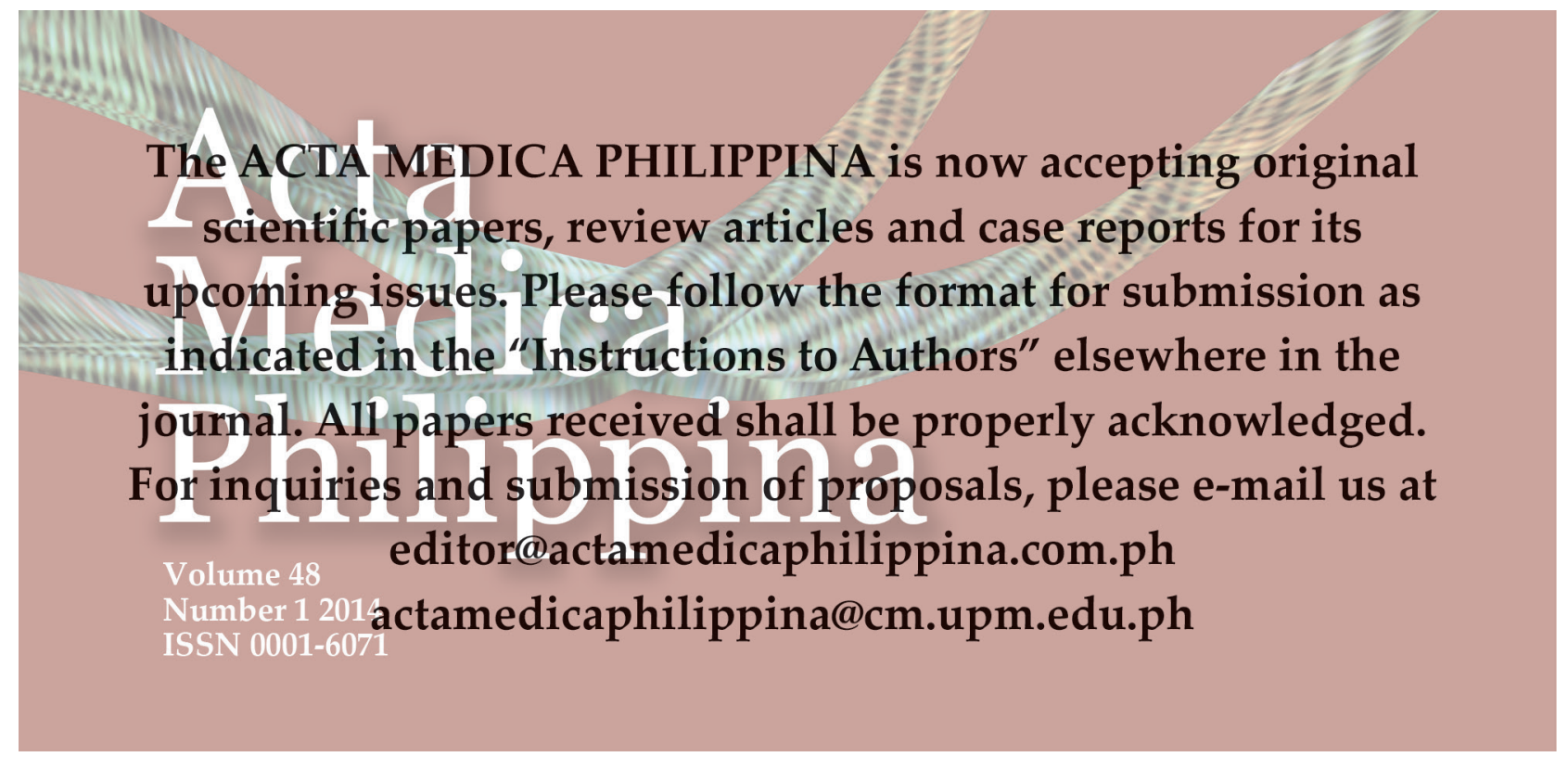

